Janez Orešnik

Ljubljana

\title{
FOUR MODERN ICELANDIC DEVOICING RULES
}

Summary. ${ }^{1}$ Modern Icelandic generative phonology contains devoicing rules responsible for the partially devoiced character of the final segments of words like dag, for the voicelessness of the stem final segments in words like dag-s, rusl(-s), and for the voicelessness of the segments followed by $t$ in words like spal-t, skamm-t (the latter in southern pronunciation only). - One detail worth emphasizing: if the rules presented here are correctly formulated, the feature [voiced] is not distinctive in the Modern Icelandic phonological segments $/ \mathrm{b} \mathrm{d} \mathrm{g/.}$

1.1. The phonological component of Modern Icelandic grammar contains the following CONTINUANT DEVOICING rule:

(1) []$\rightarrow[$ - voiced $] /[+$ syllabic $]\left[\begin{array}{l}\overline{- \text { tense }} \\ + \text { continuant } \\ \left\{\begin{array}{c}\text { - coronal } \\ \text { - anterior }\end{array}\right.\end{array}\right]+[-$ voiced $]$

I.e. any non-coronal or non-anterior lax continuant is devoiced if immediately preceded by a syllabic segment and immediately followed by the morpheme boundary and a voiceless phonological segment. - At the point in the derivation when the Continuant Devoicing rule (1) applies, LAX (= non-TENSE) segments are simply short. The features VOICED, CONTINUANT, ANTERIOR, and CORONAL are to be understood in the sense of Chomsky and Halle 1968, see especially table (1) on pp. 176-77. For SYLLABIC, see ibidem, table (67) on p. 354; vowels are the only syllabic segments of Modern Icelandic. - It follows from the list given here sub (2), and from the formulation of the Continuant

1 My thanks are due to Miss Margaret G. Davis, who has improved the style of the paper. All errors are my own. The theoretical framework and the terminology of this paper are those of generative phonology as expounded by Chomsky and Halle 1968. Non-phonetic representations are bounded by the obliques, $/ /$, except in phonological derivations, where the obliques are omitted. 
(2) Lax voiced continuant phonological segments of Modern Icelandic: ${ }^{2}$
(a) coronal: / $\mathrm{A} \mathrm{r} \mathrm{l} /$
(c) anterior: / $/ \mathrm{v}$ d/
(b) non-coronal: / $\mathrm{v}$ q'
(d) non-anterior: /q $\mathrm{r} /$

Devoicing rule (1) that the rule applies, in certain environments, to the Icelandic segments $/ \mathrm{v} q \mathrm{r} /$, changing them to $/ \mathrm{f} \times \mathrm{r} /$, respectively. ${ }^{3}$ The reason for the very general formulation to the right of the plus will become evident below, in section 1.3. I am setting up rule (1) to account for the consonantal alternations in Modern Icelandic simplex words of the type exemplified in $(3 \mathrm{a}, \mathrm{b})$. 'That the application of the rule must be limited to short / $\mathrm{v} \mathrm{q} /$, can be seen from the examples given in $(3 \mathrm{c}-\mathrm{e})$.

(3)

(a) haf 'sea'
vor 'spring',
dagur 'day'
(b) ákafur 'violent'

akur 'acre' auđugur 'wealthy'

(c) bad 'batl''

tal 'talk'

heimur 'world'

venja 'accustom'

hringur 'ring'

(d) höfud 'head'

gamall 'old'

atóm 'atom'

alinn 'fed'

vikingur 'viking'

(e) kjarr 'thicket'

ball 'dance'

gramm 'gram'

madur 'man' voiced stem final $C$

gen. pl. haf-a

gen. pl. vor-a

gen. pl. dag-a

nom. sg. m. ákaf-ur

dat. sg. akr-i

nom. sg. m. audug-ur

gen. sg. bact-s

gen. sg. tal-s

gen. pl.tal-a

gen. sg. heim-s

gen. pl. heim-a

lp. sg. pres. ind. med. oen-st

lp. sg. pres. subj. ven-j-i

gell. sg. hring-s

gen. pl. hring-a

gen. sg. höfud-s

gen. pl. höfd-a

gen. sg. m. gamal-s

gen. sg. atóm-s

gen. sg. m. alin-s

gen. sg. víking-s

gen. sg. kjarr-s

dat. sg. kjarr $-i$

gen. sg. ball-s

dat. sg. ball-i

gen. sg. gramm-s

dat. sg. gramm-i

gen. sg. mann-s

dat. sg. mann $i$ voiceless stem final $\mathrm{C}$

gen. sg. $h a f-s$

gen. sg. vor-s

gen. sg. dag-s

gen. sg. m. ákaf-s nom. sg. ntr. ákaf-t

gen. sg. akur-s

gen. sg. m. audug-s nom. sg. ntr, audiug-t 
The morpheme boundary posited in the structural description of the Continuant Devoicing rule (1) reflects the fact that the only segments which cause loss of voice in simplex words under rule (1) are /s/ and $/ t /$, i.e. the only voiceless segments which can occur immediately to the right of the morpheme boundary in simplex words. (Words such as sterkur 'strong', with voiceless $r$ in all their case forms, contain a phonological voiceless $/ \mathrm{r} /$.) However, I am not aware of any compelling reason for the morpheme boundary to be obligatorily present in the structural description of the Continuant Devoicing rule (1).

It is here stipulated that any segment to be devoiced by the Continuant Devoicing rule (1) be immediately preceded by a vowel. This reflects the fact that rightmost voiced consonants in consonantal groups are not devoiced by that rule. For examples of consonantal strings which do not undergo rule (1), see (4 a), in which Einarsson's (1945) transcriptions are presented. (On the basis of the situation in compound words, cf. section 1.3, Bérkov-Böđvarsson 1962 can be assumed to concur.) A

(4) Einarsson's transcriptions s.vv.:
(a) horf 'direction' starf 'work' gólf 'floor' kálfur 'calf'
(b) torf 'sod' úlfur 'wolf'

similar situation obtains in compound words, see section 1.3 below. On the other hand, Blöndal 1920-24 devoices the rightmost segments in all consonantal strings if they satisfy the structural description of the Continuant Devoicing rule (1), ignoring the [+ syllabic] segment of the structural description of the rule. Thus, the genitive singular forms analogous to those quoted in (4 a) are all transcribed with [f] instead of $[\mathrm{v}]$; see, for instance, Blöndal's arf-s, s.v. arfur, and similarly in compound words, cf. section 1.3 below. Einarsson has such transcriptions only seldom; for examples, see $(4 \mathrm{~b})$. I interpret this situation as indicating that Icelandic has reformulated its Continuant Devoicing rule (1) since Blöndal's time, limiting its domain to consonants immediately preceded by a vowel. (Einarsson's forms given sub $(4 \mathrm{~b})$ above are thus sporadic remnants of the older pronunciation.) I assume that the change can be ascribed to the interaction of the Continuant Devoicing rule (1) and of the Cluster Devoicing rule (10), on which see section 2 below,

${ }^{2}$ Note that nasals are non-continuant in the distinctive feature system of Chomsky and Halle 1968. Here and elsewhere in this paper the symbol of denotes a voiced velar continuant.

${ }^{3}$ Boldface indicates voicelessness. 
but I am not able to describe the mechanism which has putatively caused the change. The matter deserves separate treatment.

On the other hand, Blöndal 1920-24, Einarsson 1945, and BérkovBöđvarsson 1962 unanimously indicate, in their respective transcriptions, the devoicing of two consonants immediately preceding the morpheme boundary whenever the consonant immediately following the morpheme boundary is $/ t / / / \mathrm{CC}+t /$, where both devoiced consonants pertain to the set $\{/ \mathrm{v}$ r q/ $\}$ ): e.g. nom./acc. sg. ntr. parf-t, with voiceless $r$ and $f$, of barfur 'useful'. Moreover, the devoicing is indicated in the $l$ of $/ \mathrm{lC}+\mathrm{t} /$, where $/ \mathrm{C} /$ pertains to the set $\{/ \mathrm{v} \mathrm{r} /\}$, although so far no phonological rule is known which would devoice the $l$ in such an environment; see the discussion of sjálf-t in footnote 13. However, in no single case is the transcription with voiceless $r / l$ and $f$ the only one given; it is always accompanied by a transcription not containing the [f] intervening between the liquid and the $t$. Thus there is [bart], which is a normal form. easily derived by aid of the Continuant Devoicing rule (1) after the deletion of $/ \mathrm{v} /$. I evaluate the situation just described as follows. The forms pronounced without [f] are normal; those pronounced with [f] and voiceless $l$ are artificial. If this evaluation should prove wrong, my Continuant Devoicing rule (1) will have to undergo a major revision.

1.2. In some cases the correct phonetic representations seem to depend on the assumption that the Continuant Devoicing rule (1) is preceded by some other phonological rule in the ordering. Two such cases will now be mentioned briefly sub (I-II).

(I) The genitive singular of the noun bragd 'trick' is bragd-s, often pronounced [braxs]. Unless we are willing to see an exception in the latter form, its phonological representation must be /braqd $+\mathrm{s} /$. (The velar cannot be voiceless, as it is on the phonetic level in the genitive singular, because it would then have to be voiceless in the phonological representation of the nom. sg. bragd as well, with the result that the Cluster Devoicing rule, discussed below, in section 2, would - wrongly - devoice the stem final $d$ of this form.) To achieve the phonetic representation [braxs], a rule deleting $d$ between $g$ and $s$ has to be posited, and the derivation must be assumed to proceed as follows:

(5)

$₫ \rightarrow \emptyset / q-s$

Continuant Devoicing rule (1)

$$
\begin{aligned}
& \text { braqd }+\mathrm{s} \\
& \text { braq }+\mathrm{s} \\
& \text { brax }+\mathrm{s} \\
& \text { [braxs] }
\end{aligned}
$$

Thus the d-deletion rule must precede the Continuant Devoicing rule (1).

(II) The nom./acc. sg. ntr. of margur 'many' is marg-t [mart], with voiceless $r$ and without $g$. Unless marg-t is allotted the status of an exception, for which there seems to be no need, its $r$ cannot be under- 
lyingly voiceless in the framework of the present paper, for this would require the $r$ to be voiceless in the phonological representation of, say, nom. sg. masc. margur; this, however, would lead to a wrong result on the phonetic level, for no rule has been posited which could voice the $r$ in margur. Consequently the phonological representation of margt is $/ \operatorname{marg}+t /$, with voiced $r$. The derivation of margt proceeds as follows:

(6)

$$
\begin{array}{ll}
\mathrm{g} \rightarrow \emptyset / \mathrm{r}-\mathrm{t} & \operatorname{marg}+\mathrm{t} \\
\text { Continuant Devoicing rule (1) } & \operatorname{mar}+\mathrm{t} \\
& \operatorname{mar}+\mathrm{t} \\
\text { [mart] }
\end{array}
$$

Since $/ g /$ is not distinctively voiceless (cf. section 1.3), the Continuant Devoicing rule would not be able to devoice the $r$ of margt if $/ g /$ were still present in the representation when the Continuant Devoicing rule applied. Therefore it is necessary to postulate the ordering, the g-deletion rule first, the Continuant Devoicing rule next. (The argument of this paragraph is valid only for the northern form margt; in the homophonous and synonymous southern margt, the T-Devoicing rule, discussed below, in section 4 , may be responsible for the devoicing of the $r$.)

1.3. The Continuant Devoicing rule (1) applies in compound words as well. ${ }^{4}$ See the illustrations in $(7 \mathrm{a})$. That the rule applies only when the left constituent of the compound word ends in $/ \mathrm{v} /$, or $/ \mathrm{r} / \mathrm{h}$ or $/ \mathrm{q} /$, follows from the fact that other sounds than these are not devoiced in

4 Within the framework described here, a voiced $/ \mathrm{v} /$ must be posited in, say, haf 'sea' on the phonological level. Not so in the compound words like haf-sild '(kind of) herring'; here a phonological /f/ is not out of the question. 'True enough, a phonological boundary has to be posited between constituents of compound words in Modern Icelandic (Orešnik 1971 and footnote 15 below), and the only conceivable natural motivation of this boundary is achieved if at least ( $n-1)$ of the $n$ constituents of any compound word are identified with some simplex in the lexicon. However, this identification need not be exhaustive. As is well known, simplexes can assume special forms when incorporated into compound words as their constituents (Bloomfield 1933: 225, 229). Thus it is conceivable that beside the stem /hav/ there is a compounding variant stem /haf/, and that the latter is used in haf-sild. Similarly, adför 'attack' when pronounced with [p] (as it sometimes is, see Bödvarsson 1963 s.v. $d$ ), and adferd 'method' when pronounced with $[p]$ (as it sometimes is, see Gudfinnsson 1946: 71), are not necessarily counterexamples to the Continuant Devoicing rule (1), because they can be assumed EITHER to contain a compounding stem $a p$-in the speech of those speakers who use the pronunciations just indicated, OR to have become simplex words through the loss of the boundary between the two constituents. (There may be even other possibilities.) Such examples could be easily multiplied.

Still, it is a fact that the compound-internal sandhi obeys the Continuant Devoicing rule, in that it does not allow segment clusters which are destroyed by the Continuant Devoicing rule in simplex words. I interpret this situation as an argument for the view that in the majority of cases the identity of the left constituents of compound words with some simplex words of the lexicon is exhaustive in the sense intended here. 
the said position, see $(7 \mathrm{~b})$. It can be seen in $(7$ a) that the segments which cause devoicing are not limited to $/ \mathrm{s} /$ and $/ \mathrm{t} /$, as in simplex words. It must also be noted that the lax constituent initial $b, d$, g, although phonetically voiceless in the speech of most speakers, do not act as devoicing segments, see (7 c), and consequently cannot be voiceless phonologically. The implications of this situation for the phonological theory are as yet unclear to me.

(7) (a) The final segment of the left constituent is phonetically voiceless: af-komandi 'descendant' for-seti 'president'

lög-frædingur 'lawyer', and many other examples

(b) The final segment of the left constituent is phonetically voiced: sam-kennd 'sympathy' grammófón-plata 'record' bíl-slys 'automobile accident' vid-koma 'touch', and many other examples

(c) The final segment of the left constituent is phonetically voiced although the constituent initial $b, d, g$ are phonetically voiceless:
haf-gola 'sea breeze' sér-deilis 'especially' dag-bók 'diary'

\author{
sam-band 'connection' \\ ein-göngu 'exclusively' \\ til-bod 'offer' \\ vidt-bót 'addition'
}

As far as the devoicing of strings of voiced consonantal segments is concerned, the situation in left constituents of compound words is parallel to that obtaining in simplex words, cf. section 1.1 above. Blöndal's transcriptions are as predicted by the Continuant Devoicing rule (1) if the [+ syllabic] segment of the structural description of the rule is ignored; e.g. torf-pak 'sod roof' is transcribed with. [rf]. Einarsson's transcriptions only seldom follow Blöndal's; torf-pak is transcribed with [rf] in Einarsson as well, whereas many other words, e.g. starf-semi 'activity', contain $[\mathbf{r v}]$. The transcriptions in Bérkov-Bödtvarsson do not indicate devoicing in comparable situations at all; even torf-pak is transcribed with $[\mathrm{rv}]$.

In one respect, however, the compound words do not follow the simplexes: in the behaviour of constituent final strings such as /rv/ before constituent initial $/ t /$. While the nom,/acc. sg. ntr. djarf-t, of djarfur 'daring', is transcribed with $[\mathbf{r}(f) t]$ in the three handbooks consulted, the compound djarf-takur 'daring' is transcribed with voiced $r$ in Blöndal and Bérkov-Böđvarsson. (There is no suitable example of the kind in Einarsson.) This supports my claim that the transcriptions with [xft] of words such as djarft are spurious. 
1.4. To some extent, the Continuant Devoicing rule (1) also applies to any word final segment not separated from the immediately following word by a phonetic pause. I base this statement on two relatively large published samples of transcribed connected speech, Malone 1923 and Bergsveinsson 1941, which I have investigated. The statistical results of this investigation are summarized in table (8). ${ }^{5}$ It can be seen there that $/ \mathrm{r} /$ obeys the Continuant Devoicing rule (1) in word final position when no phonetic pause immediately follows it, and the next word begins with a distinctively voiceless sound (not $b, d$, or $g !$ ). The data on $/ \mathrm{v} \mathrm{q} /$ are statistically insignificant, and caution is indicated because of the fact that there is no instance of total devoicing of $/ q /$ in the two sources, whereas there are at least solitary examples of partially devoiced or even voiced /q/. On the other hand, the sentence ég sagdi 'I said' is to be found transcribed in the handbooks, always either with voiceless word final $[x]$, or without any consonant at all in the left word (see, for instance, Einarsson 1945: 23 and Bérkov-Böđtvarsson 1962: 962).

(8) The sounds mentioned in the present table occur in word final position, are immediately followed by a distinctively voiceless word initial sound, and no phonetic pause intervenes between the two.

$\begin{array}{lrc}\text { (a) /r } \mathrm{v} \mathrm{q} /: & \text { Malone } 1923 & \text { Bergsveinsson 1941 } \\ \text { voiceless [r] } & 31 & 18 \\ \text { partially devoiced [r] } & 1 & 1 \\ \text { voiced [r] } & 1 & 1 \text { (long } r \text { ) } \\ \text { [f] } & 0 & 1 \\ \text { partially devoiced [v] } & 0 & 0 \\ {[\mathrm{v}]} & 0 & 0 \\ {[\mathrm{x}]} & 0 & 0 \\ \text { partially devoiced [q] } & 2 & 0 \\ \text { [q] } & 1 & 1 \\ \text { (b) other sounds: } & 18 & 13 \\ \text { voiced sound } & 2 & 10 \\ \text { partially devoiced sound } & 0 & 0 \\ \text { voiceless sound } & & \end{array}$

Number of examples in

${ }^{5}$ Malone 1923 is a little difficult to interpret. Line $d$ of his transcription is essential in the respect under consideration: if the column under the segment observed contains figures 2 or 3 in line $d$, the segment is voiced; if the column contains figures 8 or 9 in the same place, the segment is voiceless; a dot instead of a figure means that the segment has the same specification of the feature [voiced] as the immediately preceding segment; a closing parenthesis between two symbols in line $d$ means that the segment to the left of the parenthesis is partially assimilated in voice to the segment immediately to the right of the parenthesis.

The statistics on Bergsveinsson 1941 are based on his narrow transcription, i.e. on line $\mathrm{c}$ of his texts I and II. 
In more than a few cases included in table (8) the critical segments are partially devoiced although we would expect them to be voiceless, or voiced. Since the acoustic difference between voiced/voiceless and partially (de)voiced sounds is difficult to hear, especially in quick speech, such examples are here not considered counterexamples to the Continuant Devoicing rule (1).

An experimental field investigation of the devoicing in inter-word sandhi remains a desideratum.

2.1. The Continuant Devoicing rule (1) cannot account for the consonantal alternations exemplified in (9), where \# denotes a phonetic

vopn 'weapon'

r'usl 'rubbish'

gutl 'dabbling'

tagl 'tail'

pukr 'secret dealing'

fálm 'fumbling'

uml 'mumbling'

klifr 'climbing' voiced stem final $\mathrm{C}$

dat. sg. popn-i

dat'. sg. rusl-i

dat.sg. gutl-i

dat. sg. tagl-i

dat. sg. pukr-i

gen. sg. fálm-s

dat. sg. fálm-i

gen.sg. uml-s

dat. sg. uml-i

nom. sg. klifr $\#^{7}$

dat. sg. klifr $r i$ voiceless stem final $\mathrm{C}$

nom. sg. popn\#

gen. sg. vopn-s

nom. sg. rusl \#

gen. sg. rusl-s

nom. sg. gutl\#

gen. sg. gutl-s

nom. sg. tagl\#

gen. sg. tagl-s

nom. sg. pukr\#"

Dialect pronunciation with stop before $d$ :

sagdur 'said'

hafdur 'had' nom. sg. m. sagd-ur

nom. sg. m. hafd-ur nom. sg. f. $s \ddot{g} g d \#$

nom. sg. f. höfd\#

pause. Rule (1) cannot devoice the stem final segments in the forms of the rightmost column of (9), because the segments to be affected are either word-final or non-continuants and/or anterior AND coronal. To account for these voice alternations, I posit the following CLUSTER DEVOICING rule (10):

(10) [- syllabic $] \rightarrow[$ - voiced $] /$ not $[+$ voiced $]-\left\{\begin{array}{l}+[\text { - voiced }] \\ \#\end{array}\right\}\left(\begin{array}{l}\text { a }) \\ (\mathbf{b})\end{array}\right.$

- The $r$ of the nom. sg. pukr is totally voiceless, not only partially devoiced. My source of $p u k r$, without epenthetic $u$, is Gudfinnsson 1946: 144 .

7 The $r$ of the nom. sg. klifr is partially devoiced when followed by a phonetic pause. It is, however, not voiceless, as it should be if the Cluster Devoicing rule were not blocked by the presence of voiced [ $v$ ] in the word. My sources for klifr, without epenthetic $u$, are Blöndal 1920-24, Bérkov-Böđvarsson 1962, Böđvarsson 1963, etc. 
I. e. any non-syllabic segment is voiceless if immediately preceded by a segment that is not voiced, and immediately followed by the word boundary, or by the morpheme boundary AND a voiceless segment, in that order. - By "a segment that is not voiced" I mean any phonologically voiceless segment or any segment which is neither voiced nor voiceless at the time of the application of rule $(10) .^{8} / \mathrm{b} \mathrm{d} \mathrm{g} /$ are segments of the latter type.

By way of illustration consider a few forms of rusl 'rubbish': the phonological representation of the stem is $/ \mathrm{rusl} /$, with voiced $/ 1 /$. The voiced stem final segment is preserved before desinences beginning with a vowel, e.g. dat. sg. rusl-i. Since $/ 1 /$ is preceded by a voiceless /s/, rule (10) applies in the nom. sg. rusl, where $/ \mathrm{l} /$ is word final, and in the gen. sg. rusl-s, where it is followed by the morpheme boundary and the voiceless desinence $/ \mathrm{s} /$, and changes $/ \mathrm{I} /$ into the phonetically voiceless [I] No such processes apply in, say, uml 'mumbling", for /1/ is here preceded by a voiced $/ \mathrm{m} /$.

The following segments are devoiced by the Cluster Devoicing rule (10): /m n $1 \mathrm{l} /$ and - in dialect - /d/. For examples, see (9).

In all the examples known to me in which case (a) of rule (10) applies, the devoiced segment is immediately followed by the morpheme boundary. For this reason the morpheme boundary has been posited in (10 a). However, I am not aware of any compelling reason for it to be there.

Case (b) of the Cluster Devoicing rule (10) could be a part of the Word Final Devoicing rule (15), discussed below, in section 3. It would be natural to say that voiced non-syllabic segments are totally devoiced if preceded by a segment that is not voiced, and only partially devoiced otherwise, in the environment of the Word Final Devoicing rule (15). I am not able to choose between these alternatives. Below I tacitly assume, for purely practical reasons, that the Cluster Devoicing rule (10) is correctly formulated.

2.2. In some cases the correct phonetic representations seem to depend on the assumption that the Cluster Devoicing rule (10) is preceded by some other phonological rule in the ordering. Two such cases will now be briefly mentioned sub (I-II).

(I) If the phonological representation of the stem of fjall 'mountain' is /fjadl/, and if the alternation [dl $\sim \mathrm{l}]$ of the nom./acc. sg. fjall vs. gen. sg. fjall-s [fjals] is due to a d-deletion rule which deletes the $/ d /$ in the segment group /dls/ whenever the three segments involved pertain to

8 No systematic status can be claimed for the ad hoc features NOT [+ VOICED] used in the formulation of the Cluster Devoicing rule (10), and [PARTIALLY VOICED] used in the formulation of the Word Final Devoicing rule (15), until more is known about the distinctive features of Modern Icelandic consonantal segments. 
the same simplex word (contrast fjall-safn 'gathering of sheep in mountains', with [dls]), then this rule must apply before the Cluster Devoicing rule (10), or else the phonetic result would be a wrong genitive singular form, [fjals], with voiceless $l$, for the derivation of the form would proceed as follows:

Cluster Devoicing rule (10) d-deletion rule

$$
\begin{aligned}
& \text { fjadl }+\mathrm{s} \\
& \text { fjadl }+\mathrm{s} \\
& \text { fjal }+\mathrm{s} \\
& *[\text { fjals] }
\end{aligned}
$$

(II) The nouns fugl 'bird' and tagl 'tail' treat their consonant group $g l$ alike in all their respective case-forms except in the genitive singular, where fugl-s contains a spirantal $g$ and a voiced $l$, whereas the $g$ of tagl-s is a full stop, and its $l$ is voiceless. One way to account for this difference in pronunciation is to posit different segment clusters in the phonological representations of the two nouns: / fuql/ vs. /tagl/, A phonological rule (presumably the same rule which also changes $/ \mathrm{v} q /$ into stops before $n$, see Orešnik 1972) changes /q/ to /g/ before /l/ whenever the latter is not followed by a true consonant. (The stipulation that the consonant be "true" is presumably necessary, for a following / $/ \mathrm{r} / \mathrm{pro}$ bably does not block the creation of the stop.) This leaves fugl-s intact, with [q], but creates /gl/ in the remaining forms of the word. If this treatment of the difference in pronunciation between fugl-s and tagl-s is correct, the rule which changes /ql/ to /gl/ must precede the Cluster Devoicing rule (10), and the derivation of the case-form fugl proceed as follows:

$$
\begin{array}{ll}
\mathrm{ql} \rightarrow \mathrm{gl} & \text { fuql } \\
\text { Cluster Devoicing rule (10) } & \text { fugl } \\
& \text { fugl } \\
& \text { [fygl] }
\end{array}
$$

If the relative ordering of the two rules were the opposite, the Cluster Devoicing rule (10) would not have a chance to apply to /fuql/, seeing that the conditions for the application of the rule are not met by the latter representation: $/ \mathrm{q} /$ is distinctively voiced. This would leave us with no means of devoicing the $/ 1 /{ }^{\circ}$

9 To account for the difference in pronunciation between fugl-s and tagl-s, two different lexical representations were posited in each case. The same treatment is necessary to account for the two pronunciations of bragd 'trick': the southern pronunciation is [braqd], with partially devoiced stem final sound before realized phonetic pause, the northern is [brakp] in the same environment; the case-forms in which the stem is followed by a vowel contain [qd] in the South, and [gd] in the North. The phonetically correct results are guaranteed if the lexical representation of the southern stem is /braqd/, and that of the northern stem. /bragd/. The Cluster Devoicing rule (10) then applies in the northern nominative/accusative forms and devoices the word final $/ \mathrm{d} /$ into $/ \mathrm{b} /$. 
2.3. As far as I can see, the situation in compound words is such as predicted by the Cluster Devoicing rule (10). I am basing this claim on the transcriptions in Einarsson 1945 and Bérkov-Böđvarsson 1962. See (13). Blöndal 1920-24, however, italicizes the final segment of the left constituent in the types of compound words exemplified by tungl-koma and jafn-gamall in (13); according to Ófeigsson in Blöndal 1920-24: XX,

(13) environment of

segment $\mathrm{X}$ voiceless

voiceless_voiceless popn-fimi 'skill at arms'

voiceless_voiced

voiced_voiceless

voiceless_/b d g/

b d g/_voiceless

/b d g/_/b d g/

voiced_voiced

voiced_/b d g/

/b d g/_voiced final segment $X$ of the left constituent

voiced

vopn-laus 'unarmed'

tungl-koma 'new moon'10

popn-bitinn 'wounded w. arms' jafn-fretis 'on equal standing' jafn-gamall 'of the same age'

tungl-myrkoi 'lunar eclipse' tungl-braut 'lunar orbit' jafn-lyndi 'even temper'

this means that the segments in question are sometimes pronounced voiced, and sometimes voiceless, but it is not clear whether they can vacillate in the speech of the same person, or of the same community, or anything else. The Cluster Devoicing rule (10) cannot account for this vacillation, and will have to be reformulated if the transcriptions of Blöndal 1920-24 turn out to be nearer to reality than the more recent data on which this section is based.

2.4. The handbooks offer hardly any information on the behaviour of the consonantal clusters enumerated in the left column of (13) in connected speech. The Cluster Devoicing rule (10) predicts pronunciations such as those indicated in (14), where each pair of words is supposed to pertain to the same breath group. My own impressionistic observations of spoken Icelandic confirm the data presented in (14). However, a special investigation of this matter is a desideratum.

A similar treatment helps to account for the two pronunciations of blidka 'soften': the southern with $[\mathrm{pg}]$, and the northern with $[\mathrm{dk}] . / \mathrm{b} /$ and $/ \mathrm{d} /$, respectively, are posited in the lexical representation of the stem, and no devoicing rules apply in the derivations of the two pronunciation variants. Such simple treatment would not do in the case of the past participles hafdur pronounced with [b], of hafa 'have', and sagdur pronounced with non-continuant $g$, of segja 'say'. Here underlying /hav $+\mathrm{d} /$ and /saq + d/ must be posited, cf. the present-stem members of the respective verbal paradigms. A special northern rule changes $/ \mathrm{vd} /$ to $/ \mathrm{bd} /$, and $/ \mathrm{qd} /$ to $/ \mathrm{gd} /$, in the appropriate contexts.

${ }^{10}$ The pronumciation of tungl- which $I$ have in mind here and in (14) does not contain $[\mathrm{g}]$. 
(14) environment of segment $X$ voiceless_voiceless voiceless_voiced voiced_roiceless voiceless_/b d g/ /b d g/_voiceless /b d $\mathrm{g} /-/ \mathrm{b} d \mathrm{~g} /$ voiced_voiced voiced_/b d g/ /b d g/__voiced final segment $\mathrm{X}$ of the left word is voiceless voiced bopn fékk

vopn beit jafn straumur jafn baggi

3. In Modern Icelandic phonology there is also a WORD FINAL DEVOICING rule:

$$
\left[\begin{array}{l}
- \text { syllabic } \\
+ \text { voiced } \\
- \text { tense }
\end{array}\right] \rightarrow \text { partially voiced } / \text { - \# }
$$

I.e. any lax voiced non-syllabic segment is partially devoiced if immediately followed by a word boundary. (See also footnote 8.) [+ voiced] must be mentioned in the structural description of the rule, otherwise distinctively voiceless segments, e.g. $/ \mathrm{s} /$, would be turned into partially voiced sounds by this rule. At the time that the Word Final Devoicing rule (15) applies, lax non-syllabic segments are simply short. Examples
(a) bad 'bath'
hefd 'title'
dagur 'day'
emj 'cry'
öl 'ale, beer'
horf 'direction'
akur 'acre'
gamall 'old'
höfud 'head'
gaman 'fun'
talkúm 'talcum'
(b) skammur 'short'
unna 'love'
kjarr 'thicket'
ball 'dance'

\section{stem final consonant}

\section{voiced}

dat. sg. bad-i

gen. sg. hefd-ar

nom. sg. dag-ur

dat. sg. emj-i

gen. sg. öl-s

dat. sg. horf-i

dat. sg. $a k r-i$

dat. pl. göml-um

dat. sg. höfd-i

gen. sg. gaman-s

gen. sg. talkúm-s

nom. sg. f. skömm\#

partially devoiced

nom. sg. bad\#

nom. sg. hefd \# ${ }^{11}$

acc. sg. dag\#

nom. sg. emj\#

nom. sg. öl\#

nom. sg. horf\#

nom. sg. akur\# nom. sg. f. gömul \# nom. sg. höfud\# nom. sg. gaman\# nom. sg. talkúm\#

${ }^{11}$ The pronunciation of hefd which I have in mind here contains [v] before the dental. 
like hefd, emj and horf of (16) show that rule (15) must be limited to the word final position: voiced non-final non-syllabics in contact with word final segments are not partially devoiced by rule (15).

The Word Final Devoicing iule (15) accounts for the consonantal alternations of the type exemplified in $(16 \mathrm{a})$, where the simbol \# denotes a phonetically realized pause. Examples showing that the rule must be restricted to short non-syllabic segments are given in (16 b).

Einarsson 1945: 5, 25 asserts that the consonants in the endings -inn and -um retain some length and are voiced, at least in careful speech. These data are disputed. As regards unstressed -inn, they are stated similarly in Einarsson 1927: 38, 79, in Gudfinnsson 1946: 68 (where the author describes the length of $[\mathrm{n}]$ in the said ending as vacillating between voiced long [n] and partially devoiced short [n]), by implication also in Kress 1963, e.g. p. 57, as pointed out by Benediktsson 1965: 112. On the other hand, Benediktsson l.c. believes that no such vacillation exists, except perhaps in an affected lecture style of pronun ciation. As to the unstressed ending - $u m$, the length of its $m$ is asserted by Einarsson 1927: 38, 79 and by Kress 1963: 33. Benediktsson 1965: 112 can be construed as denying the existence of any special length of $m$ in -um. Whatever the truth about this quantity problem, the Word Final Devoicing rule (15) predicts that word final $m$ and $n$ will be voiced when long, and partially devoiced when short.

On the phonetic level, the effects of the Word Final Devoicing rule (15) can only be observed at the absolute end of breath groups, i.e. at phonetically realized pauses (Einarsson 1945: 24). Although the environment of rule (15) mentions the word boundary, and although the latter is present in the phonological representations of nouns with suffixed article (Orešnik 1972, app. B), and assumedly present in the phonological representations of compound words (cf. footnote 15), the Word Final Devoicing rule (15) never seems to leave any traces behind in nouns with suffixed articles or in compound words. We return to this fact in section 4.3 below.

4.1. The Continuant Devoicing rule (1), the Cluster Devoicing rule (10), and the Word Final Devoicing rule (15) apply with equal force in all Modern Icelandic dialects, as far as I know. This is not the case with the T-DEVOICING rule to which we now pass. The T-Devoicing rule must be stated separately for southern and northern dialect areas: ${ }^{12}$

(17) [-syllabic] $\rightarrow[$ - voiced] / - $t$ in southern pronunciation

I.e. in southern pronunciation any non-syllabic segment is devoiced if immediately followed by $/ \mathrm{t} /$. Rule (17) accounts for consonantal alternations like those exemplified in (19).

12 The terms SOUTHERN and NORTHERN are approximate labels. For a stricter geographical delimitation of the two pronunciations, see Gudfinnsson 1964: $17-43$. 
The northern counterpart of rule (17) is as follows: (18) $[+$ lateral $] \rightarrow[-$ voiced $] /-t$ in northern pronunciation

I.e. in northern pronunciation any /I/ is devoiced if immediately followed by $/ t /$. Rule (18) accounts for the consonantal alternations exemplified sub (19a). There are no comparable alternations in the words given sub $(19 \mathrm{~b})$, in northern pronunciation, hence the need for the more restricted northern T-Devoicing rule (18). The southern version (17) is thus seen to be more general, and presumably easier for languagelearning children to learn and remember, than the northern rule (18). This may be one of the factors contributing to the spread of (17) at the expense of (18).

(a) svalur 'cool'

(b) skemma 'damage' vanur 'used to' hringja 'ring' consonant before the hyphen voiced voiceless

nom. sg. m. sval-ur

inf. skemm-a

nom. sg. m. van-ur. inf. hringj-a nom. sg. ntr. sval-t

supine skemm-t

nom. sg. ntr. van-t supine hring-t

Almost all the forms in which the T-Devoicing rule (17/18) HAS to apply seem to involve $/ \mathbf{t}$ / preceded by a morpheme boundary at the point in the derivation when the T-Devoicing rule (17/18) applies. (Words like vanta 'lack', with voiceless $n$ in all the forms of the word in southern pronunciation, do not argue against the presence of the morpheme boundary in the structural description of the T-Devoicing rule (17/18), for the voiceless $n$ can be present in the phonological representation of the word, and is thus not necessarily due to the T-Devoicing rule (17/18).) I know only four exceptions: in the singular preterite indicative of the strong verbs halda 'hold', gjalda 'pay', svelta 'be hungry', and velta 'fall', voiced and voiceless $l$ alternate with each other, as shown

(20) (a) voiceless $l$ : lp. and 3p. sg. pret. ind. active hélt, galt, sbalt, palt

(b) voiced $l: 2 \mathrm{p}$. sg. pret. ind. active and the whole sg. pret. ind. middle: hélzt, galzt, svalzt, valzt

in (20). No morpheme boundary can be posited before $t$ in the forms sub (20 a). Nor can it be plausibly argued that the forms are suppletive formations, with their voiceless $l$ not due to the operation of the T-Devoicing rule (17/18), but present in the underlying representations of these forms, for one suppletive form would then be necessary in the first and third persons singular preterite indicative active, and another in all the remaining forms of the singular preterite indicative, including the middle voice. It seems to me much more plausible that the voicelessness 
of the $l$ in the forms of $(20 \mathrm{a})$ is due to the T-Devoicing rule (12/18). ${ }^{13}$ To accommodate the forms sub (20), the morpheme boundary is not posited in the structural description of the T-Devoicing rule (17/18).

4.2. Unlike the Continuant Devoicing rule (1) and the Cluster Devoicing rule (10), the T-Devoicing rule (17/18) does not operate across the boundary between the constituents of compound words, or across the boundary between words. ${ }^{14}$ In fact, the morpheme boundary is the only boundary which does not block the T-Devoicing rule (17/18). For crucial examples in which the T-Devoicing rule (17/18) does not apply, see (21).

4.3. One reason why no attempt has been made here to collapse the T-Devoicing rule $\left(17_{i} / 18\right)$ with the Continuant Devoicing rule (1) and/or the Cluster Devoicing rule (10) is that the T-Devoicing rule $(17 / 18)$ is, unlike the other rules just mentioned, a dialect dependent rule. Another argument against the collapsing is that the T-Devoicing rule precedes the Compound Boundary rule, whereas the Continuant Devoicing rule (1) and the Cluster Devoicing rule (10) follow the said boundary rule in the ordering. This matter will now be briefly discussed.

13 The alternation between voiced and voiceless $l$ is also observed in the imperative singular of the verbs under discussion: the active form haltu contains a voiceless $l$, the middle form halztu a voiced $l$. However, the T-Devoicing rule (17/18) can account for this alternation even if its structural description contained an obligatory morpheme boundary, for the phonological representations of these forms are /hald $+\mathrm{tu} / \mathrm{and} / \mathrm{hald}+\mathrm{st}+\mathrm{tu} /$, where the morpheme boundary before/tu/ may be a rewritten stronger boudary, in which case the rewriting rule operates before the T-Devoicing rule.

The supines such as siglt of sigla 'sail' may also be relevant with respect to the morpheme boundary in the structural description of the T-Devoicing rule (and, incidentally, even with respect to the structural descriptions of some other devoicing rules). However, these supines require separate treatment because of the many problems associated with their derivation (metathesis, etc.).

Forms such as nom./acc. sg. ntr. sjálf-t, of sjálfur 'self', are partly enigmatic. One of the pronunciations of sjalft is [-lt], with voiceless $l$ and without $f$; this pronunciation is easily accounted for by the T-Devoicing rule (17/18) if the deletion of the phonological segment between $l$ and $t$ precedes the application of the T-Devoicing rule; cf. footnote 18 ad finem. Another pronunciation of sjalft contains [-lft], with voiceless $l$. This $l$ cannot be devoiced by any of the rules posited here. I evaluate the [-lft]-forms as artificial.

Guđfinnsson 1964: 17-43, especially 30 ff., reports some dialect pronunciations of sjálft. Normally his informants, school children, did not pronounce the $f$ at all, and they either devoiced the $l$ in accordance with the T-Devoicing rule in such forms (this was the normal situation), or did not devoice the $l$; in the latter case the T-Devoicing rule was only optional in their mental grammars, or they (more seldom) lacked it altogether. In rare but interesting cases the $f$ was pronounced as. [v]: [-lvt], o.c. pp. 33, 35; this pronunciation is predicted by my above devoicing rules for the dialect areas in which the northern variant of the T-Devoicing rule is in use. The Continuant Devoicing 
(21) (a) The final consonant of the left constituent is voiced:

til-tala 'proportion'

sam-tal 'conversation'

ein-tala 'singular'

vid-tal 'talk' gamal-tungla 'barren old sheep'

atóm-tákn 'symbol of chemical

element'

saman-tekning 'compilation'

höfud-tilgangur 'chief goal'

(b) The final consonant of the left word is voiced:

$\begin{array}{ll}\text { bíl tel } & \text { bidil tel } \\ \text { tóm tel } & \text { atóm tel } \\ \text { ein tel } & \text { saman tel } \\ \text { aud tel } & \text { höfud tel }\end{array}$

(Each pair of words sub (b) pertains to the same breath group.)

On the phonological level words, simplex or compound, are bounded with word boundaries. There are also boundaries between the constituents of compound words, although the precise nature of these boundaries has not yet been determined for Modern Icelandic; most likely they are word boundaries, and this assumption is accepted in the present paper. ${ }^{15}$ On the phonetic level, word boundaries are realized as phonetic

rule (1) is blocked because the $/ \mathrm{v} /$ is not preceded by a vowel; the T-Devoicing rule (18), which only affects $/ 1 /$, cannot operate because of the intervening /v/. Gudfinnsson reports cases of [-lvt] from the Northern districts only: from Eyjafjarđarsýsla (including Akureyri) and Sudur-pingeyjarsýsla. (The voiced pronunciation of the middle segment in [-lvt] cannot have been influenced by the spellings in the text which the investigator asked the children to read during the interviews; the text in question, as published by Gudfinnsson 1946: 145-46, contains the forms ljuft and lift, which could have led to spelling pronunciations with [-vt] as well, but the author reports none.)

To facilitate the exposition, I now state the pronunciations of sjálft predicted by my devoicing rules:

$\begin{array}{lll} & \text { South } & \text { North } \\ \text { with }[f] \text { or }[v] & {[-1 f t]} & {[-1 v t]} \\ \text { without }[\mathbf{f}] \text { or }[v] & {[-1 t]} & {[-1 t]}\end{array}$

The [-lft]-form is adduced in Kress 1963: 42; Kress has [telft] teflt, the supine of tefla 'play chess'.

Incidentally, the cases of the absent T-Devoicing rule, mentioned above, involve the northern variant (18). Diachronically, these are cases of rule loss, presumably due to the very narrow domain of the rule. It should be recalled that in contact with the southern variant (17) the northern rule (18) is giving way; this must be another facet of the same phenomenon.

${ }_{14}$ One apparent exception to this claim is mál-tid 'meal', which is sometimes pronounced with a voiceless l, see Blöndal 1920-24 s. v., Gudfinnsson 1946: 71, and Bérkov-Bödvarsson 1962 s.v. This word can be accounted for in the same way as adför and adferd, see footnote 4 above.

${ }_{15}$ That there must be a boundary between constituents of compound words, is proved in Orešnik 1971, where, however, the nature of that boundary was not strictly determined, although is was shown that several phonological 
of the $l$ in the forms of $\left(20\right.$ a) is due to the T-Devoicing rule (17/18). ${ }^{13}$ To accommodate the forms sub (20), the morpheme boundary is not posited in the structural description of the T-Devoicing rule (17/18).

4.2. Unlike the Continuant Devoicing rule (1) and the Cluster Devoicing rule (10), the T-Devoicing rule (17/18) does not operate across the boundary between the constituents of compound words, or across the boundary between words. ${ }^{14}$ In fact, the morpheme boundary is the only boundary which does not block the T-Devoicing rule (17/18). For crucial examples in which the T-Devoicing rule (17/18) does not apply, see (21).

4.3. One reason why no attempt has been made here to collapse the T-Devoicing rule $(17 / 18)$ with the Continuant Devoicing rule (1) and/or the Cluster Devoicing rule (10) is that the T-Devoicing rule $(17 / 18)$ is, unlike the other rules just mentioned, a dialect dependent rule. Another argument against the collapsing is that the T-Devoicing rule precedes the Compound Boundary rule, whereas the Continuant Devoicing rule (1) and the Cluster Devoicing rule (10) follow the said boundary rule in the ordering. This matter will now be briefly discussed.

13 The alternation between voiced and voiceless $l$ is also observed in the imperative singular of the verbs under discussion: the active form haltu contains a voiceless $l$, the middle form halztu a voiced $l$. However, the 'T-Devoicing' rule $(12 / 18)$ can account for this alternation even if its structural description contained an obligatory morpheme boundary, for the phonological representations of these forms are /hald $+\mathrm{tu} /$ and /hald + st $+\mathrm{tu} /$, where the morpheme boundary before/tu/ may be a rewritten stronger boudary, in which case the rewriting rule operates before the T-Devoicing rule.

The supines such as siglt of sigla 'sail' may also be relevant with respect to the morpheme boundary in the structural description of the T-Devoicing rule (and, incidentally, even with respect to the structural descriptions of some other devoicing rules). However, these supines require separate treatment because of the many problems associated with their derivation (metathesis, etc.).

Forms such as nom./acc. sg. ntr. sjálf-t, of sjálfur 'self', are partly enigmatic. One of the pronunciations of sjalft is [-1t], with voiceless $l$ and without $f$; this pronunciation is easily accounted for by the T-Devolcing rule (17/18) if the deletion of the phonological segment between $l$ and $t$ precedes the application of the T-Devoicing rule; cf. footnote 18 ad finem. Another pronunciation of sjálft contains [-lft], with voiceless $l$. This $l$ cannot be devoiced by any of the rules posited here. I evaluate the [-lft]-forms as artificial.

Gudfinnsson 1964: 17 - 43, especially 30 ff., reports some dialect pronunciations of sjálft. Normally his informants, school children, did not pronounce the $f$ at all, and they either devoiced the $l$ in accordance with the T-Devoicing rule in such forms (this was the normal situation), or did not devoice the $l$; in the latter case the T-Devoicing rule was only optional in their mental grammars, or they (more seldom) lacked it altogether. In rare but interesting cases the $f$ was pronounced as $[\nabla]:[-1 v t]$, o.c. pp. 33,35 ; this pronunciation is predicted by my above devoicing rules for the dialect areas in which the northern variant of the T-Devoicing rule is in use. The Continuant Devoicing 
(21) (a) The final consonant of the left constituent is voiced:

til-tala 'proportion'

sam-tal 'conversation'

ein-tala 'singular'

vid-tal 'talk' gamal-tungla 'barren old sheep' atóm-tákn 'symbol of chemical element' saman-tekning 'compilation' höfud-tilgangur 'chief goal'

(b) The final consonant of the left word is voiced:

bíl tel
tóm tel
ein tel
aud tel

bictil tel

atóm tel

saman tel

höfud tel

(Each pair of words sub (b) pertains to the same breath group.)

On the phonological level words, simplex or compound, are bounded with word boundaries. There are also boundaries between the constituents of compound words, although the precise nature of these boundaries has not yet been determined for Modern Icelandic; most likely they are word boundaries, and this assumption is accepted in the present paper. ${ }^{15}$ On the phonetic level, word boundaries are realized as phonetic

rule (1) is blocked because the $/ \mathrm{v} /$ is not preceded by a vowel; the T-Devoicing rule (18), which only affects $/ 1$, cannot operate because of the intervening /v/. Gudfinnsson reports cases of [-lvt] from the Northern districts only: from Eyjafjarđarsýsla (including Akureyri) and Suđur-pingeyjarsýsla. (The voiced pronunciation of the middle segment in [-lvt] cannot have been influenced by the spellings in the text which the investigator asked the children to read during the interviews; the text in question, as published by Gudfinnsson 1946: 145-46, contains the forms ljuft and lift, which could have led to spelling pronunciations with [-vt] as well, but the author reports none.)

To facilitate the exposition, I now state the pronunciations of sjálft predicted by my devoicing rules:

$\begin{array}{lll} & \text { South } & \text { North } \\ \text { with [f] or [v] } & {[-\mathrm{lft}]} & {[-1 v t]} \\ \text { without [f] or }[\mathrm{v}] & {[-\mathrm{lt}]} & {[-\mathrm{lt}]}\end{array}$

The [-lft]-form is adduced in Kress 1963: 42 ; Kress has [telft] teflt, the supine of tefla 'play chess'.

Incidentally, the cases of the absent T-Devoicing rule, mentioned above, involve the northern variant (18). Diachronically, these are cases of rule loss, presumably due to the very narrow domain of the rule. It should be recalled that in contact with the southern variant (17) the northern rule (18) is giving way; this must be another facet of the same phenomenon.

14 One apparent exception to this claim is mál-tid 'meal', which is sometimes pronounced with a voiceless $l$, see Blöndal 1920-24 s. v., Gudfinnsson 1946: 71, and Bérkov-Bödvarsson 1962 s.v. This word can be accounted for in the same way as adför and adferd, see footnote 4 above.

${ }_{15}$ That there must be a boundary between constituents of compound words, is proved in Orešnik 1971, where, however, the nature of that boundary was not strictly determined, although is was shown that several phonological 
pauses. (Phonetic pauses delimit breath groups.) Since the number of the word boundaries on the phonological level largely exceeds the number of phonetic pauses, the phonological component of Modern Icelandic (in fact, of every language) must contain a mechanism which cancels some of the phonological word boundaries during derivation. I imagine, maybe prematurely, that such a mechanism consists of rules interspersed among other phonological rules, deleting certain word boundaries or replacing them by weaker boundaries, most likely by morpheme boundaries. It is assumed here that the Modern Icelandic phonological component contains a mechanism whose duty is to replace word boundaries with morpheme boundaries, so that at the end of derivations only those word boundaries are preserved which correspond to phonetic pauses. The rules of this mechanism - let us call them BOUNDARY RULES apply at different stages in derivations. One of the earliest boundary rules affects the word boundary between a noun and a suffixed definite article (Orešnik 1972). ${ }^{16}$ A later boundary rule - let us call it the COMPOUND WORD BOUNDARY rule - replaces the word boundary between the immediate constituents of compound words with the morpheme boundary. A still later boundary rule - let us call it the INTER WORD BOUNDARY rule - replaces certain word boundaries between words with morpheme boundaries, and thus creates what are to be realized phonetically as breath groups.

We already know that, while the T-Devoicing rule (17/18) can operate across a morpheme boundary, it cannot operate across any other boundaries. On the other hand, case (a) of the Cluster Devoicing rule (10) operates freely across the word boundary between constituents of compound words, and most probably also across the inter-word word

phenomena of Modern Icelandic can be handled more satisfactorily if the said boundary is assumed to be a word boundary, than without that assumption. To the arguments of o.c. in favour of the word boundary between the constituents of compound words it can be added that one should think the boundary hetween a noun and a suffixed article to be weaker than the boundary between constituents of compound words. As the boundary between a noun and a suffixed article has been identified with a word boundary (in Orešnik 1972), it is likely that the boundary between constituents of compound words is at least as strong as a word boundary; and since the phonological theory does not provide any stronger boundary than the word boundary, the boundary between constituents of compound words is likely to be identical with the word boundary.

${ }_{10}$ Through my negligence a minus sign has been omitted in the formalized version of the Enclitic Boundary rule as printed in Orešnik 1972: 29. The formulation is therefore repeated here:

$$
\text { [ ] } \rightarrow[\alpha \text { word boundary }] /[\overline{- \text { segment }}]_{1}[-\alpha \text { enclitic }]
$$

I.e. any number of subsequent word boundaries remains if immediately followed by a non-enclitic word, and are rewritten as a morpheme boundary if immediately followed by an enclitic word. 
boundary within breath groups. Case (b) of the Cluster Devoicing rule (10) and the Word Final Devoicing rule (15) operate only at the word boundary at the end of a breath group. The Continuant Devoicing rule (1) can operate across a morpheme boundary and across the word boundary between constituents of compound words, whereas it is unclear whether it can apply across the inter-word word boundary.

A natural way to account for this situation is to assume that the devoicing rules (1), (10), (15), and (17/18) are interspersed among the boundary rules in such a way that the state of affairs just described follows as a consequence of the relative rule orderings posited. The orderings which accomplish just this are stated in (22), q.v. The generally

\author{
T-Devoicing rule (17/18) \\ Compound Word Boundary rule \\ Inter Word Boundary rule \\ $\left\{\begin{array}{l}\text { Cluster Devoicing rule (10) } \\ \text { Word Final Devoicing rule (15) }\end{array}\right\}$ \\ Breath group boundary $\rightarrow$ phonetic pause ${ }^{17}$
}

accepted conventions concerning rule orderings ensure the desired results. For instance, no word boundary is mentioned in the T-Devoicing rule (17/18), and the rule applies before the word boundaries between constituents of compound words have been rewritten as morpheme boundaries; this automatically ensures that the T-Devoicing rule (17/18) applies only in simplex words and in those constituents of compound words which are not themselves compound words. No word boundary is mentioned in the structural description of case (a) of the Cluster Devoicing rule (10). This means that the rule cannot operate across those word boundaries present in the representations at the time when rule (10) applies. Since, however, the word boundary between constituents of compound words and the inter-word word boundary had been rewritten as the morpheme boundary by the time rule (10) applies, the rule can operate freely in simplex as well as in compound words, and between words within breath groups. On the other hand, a word boundary is mentioned in case (b) of the Cluster Devoicing rule (10) and in the Word Final Devoicing rule (15). As the Compound Word Boundary rule and the Inter Word Boundary rule have applied by the time that rule (10) applies, the structural description of its case (b) is only met at the breath-group final word boundaries. Similarly, at the time that the Word Final Devoicing rule (15) applies, all the word boundaries within breath groups; except those bounding the breath groups, have been rewritten

${ }_{17}$ The relative ordering of the rules within the braces is at present unclear to me. The Continuant Devoicing rule (1), not mentioned in (22), certainly follows the Compound Word Boundary rule. Its ordering with respect to later boundary rules is at present unclear to me. 
as morpheme boundaries; consequently no effects of rule (15) can be observed in compound words or in words not followed by a phonetic pause. $^{18}$

\section{REFERENCES}

Benediktsson, Hreinn. Review of Kress 1963. Islenzk tunga 6: 109-17. Reykjavík, 1965.

Bergsveinsson, Sveinn. Grundfragen der isländischen Satzphonetik. Phonometrische Forschungen, Reihe A, Band 2. Copenhagen and Berlin, 1941.

Bérkov, Valerij P., and Árni Böđvarsson. Íslenzk-rússnesk ordabók, Moscow, 1962.

Blöndal, Sigfús. íslenzk-dönsk ordabók. Reykjavík, 1920-24.

Bloomfield, Leonard. Language. New York, 1933.

${ }^{18}$ As the relation of the devoicing rules to the Enclitic Boundary rule mentioned above is not relevant to the problem under discussion, the matter has been relegated to this footnote. The T-Devoicing rule (17/18) FOLLOWS the Enclitic Boundary rule; hence, the Continuant Devoicing rule (1) and the Cluster Devoicing rule (10) follow it as well. For evidence that the T-Devoicing rule follows the Enclitic Boundary rule in the ordering, consider the derivation of the supine rignt of rigna 'rain'. The derivation of the definite dat. sg. hring-num of hringur 'ring' is added for comparison; the word boundary and the morpl /in/ are justified in Orešnik 1972, app. A, B:

\begin{tabular}{|c|c|c|}
\hline \multirow{4}{*}{$\begin{array}{l}\text { Vowel Syncope rule } \\
\text { metathesis } \\
\text { nasal assimilation } \\
\text { Enclitic Boundary rule } \\
\text { b, } d, g \rightarrow \emptyset / D \text {, } \rightarrow \\
\text { T-Devoicing rule }\end{array}$} & rign + D + t & liriNg \#\# in + um \\
\hline & $\overline{\operatorname{ring}}+\mathrm{D}+\mathrm{t}$ & \\
\hline & $\mathrm{riNg}+\mathrm{D}+\mathrm{t}$ & \\
\hline & $\begin{array}{l}\text { riN }+t \text { (2 applications) } \\
\text { riN }+t \text { (southern only) }\end{array}$ & hriN $+n+u m$ \\
\hline
\end{tabular}

(The $/ \mathrm{D} /$ in the phonological representation of rignt is phonologically a cover symbol for a dental consonant, and morphologically the dental suffix. Its presence in the phonological representation of the supine is not proved; however, the point made here remains valid even if the true phonological representation of rignt is just /rign $+t / . / N /$ represents the velar nasal.) The last three lines of the derivation are relevant to the point under consideration. The relative ordering of the Enclitic Boundary rule and of $b, d$, $g \rightarrow \emptyset / \_D$ depends crucially on the question as to whether the deletion of $g$ in rignt is performed by the same rule as the deletion of $g$ in the definite dat. sg. hringnum. It is assumed here that this is the case. It is claimed in Orešnik 1972 that the loss of $g$ in hringnum follows the Enclitic Boundary rule. Hence, $g \rightarrow \emptyset / D$ follows the Enclitic Boundary rule as well. Since the T-Devoicing rule (17/18) can only apply to the nasal of rignt after the deletion of $g$, the T-Devoicing rule must follow $b, d, g \rightarrow \emptyset / \ldots$. Hence, a fortiori, the T-Devoicing rule must follow the Enclitic Boundary rule. Consequently the Continuant Devoicing rule (1) and the Cluster Devoicing rule (10) also follow the Enclitic Boundary rule.

Incidentally, the derivation of rignt shows that the present formulation of the T-Devoicing rule presupposes that a number of other phonological rules precede it in the ordering and thus create the conditions for its operation: the metathesis rule; nasal assimilation; $b, d, g \rightarrow \emptyset / \_D$. Other rules which must precede the T-Devoicing rule include the loss of $/ \mathrm{v} /$ between $/ \mathrm{l} /$ and dental, cf. nom./acc. sg. ntr. hál(f)t of hálfur 'half'. 
Bödvarsson, Árni, ed. Íslenzk ordabók handa skólum og almenningi. Reykjavík, 1963.

Chomsky, Noam, and Morris Halle. The Sound Pattern of English. New York, 1968. 1927.

Einarsson, Stefán. Beiträge zur Phonetik der isländischen Sprache. Oslo,

Einarsson, Stefán. Icelandic Grammar. Texts. Glossary. Baltimore, 1945. I have used the slightly revised fifth printing of 1967.

Gudfinnsson, Björn, Mállýzkur. Vol. I. Reykjavík, 1946.

Gudfinnsson, Björn. Um islenzkan framburd. Mállýzkur II. Edited and prepared for the press by ólafur M. Olafsson and óskar Ó. Halldórsson. Studia islandica vol. 23. Reykjavík, 1964.

Kress, Bruno. Laut und Formenlehre des Isländischen. Halle/Saale, 1963. 1923.

Malone, Kemp. The Phonology of Modern Icelandic. Menasha, Wisconsin,

Orešnik, Janez. "On the phonological boundary between constituents of Modern Icelandic compound words." Linguistica 11: 51-59. Ljubljana, 1971.

Orešnik, Janez. "On the epenthesis rule in Modern Icelandic." Arkio för nordisk filologi 87: 1-32. Lund, 1972.

\section{Povzetek}

\section{ŠTIRI NOVOISL_ANDSKA RAZZVENITVENA PRAVILA}

Novoislandska generativna fonologija vsebuje štiri razzvenitvena pravila, ki povzročajo delno razzvenitev končnih glasov $\mathrm{v}$ besedah kot dag, popolno razzvenitev končnih glasov osnove $\vee$ besedah lkot dag-s, rusl(-s) in popolno razzvenitev glasov pred $t \mathrm{v}$ besedah kot sbal-t, skamm-t ( $\mathrm{v}$ zadnji samo $\mathrm{v}$ južnem izgovoru). - Od nadrobnosti je vredno omeniti: če so tu predložena pravila izrečena pravilno, fonološka oznaka [zveneč] ni razločevalna (distinktivna) $\mathrm{v}$ islandskih fonoloških enotah $/ \mathrm{b} \mathrm{d} \mathrm{g} /$. 